\title{
Агроекологія, рослинництво
}

\section{Урожайність сортів пшениці м'якої ярої у різних екологічних зонах вирощування}

\author{
Близнюк Р. М., Березовський Д. Ю. \\ Демидов О. А., доктор сільськогосподарських наук, член-кореспондент НААН \\ Хоменко С. О., кандидат сільськогосподарських наук
}

Миронівський інститут пшениці імені В. М. Ремесла НААН Україна, 08853, с. Центральне, Миронівський район Київської обл. e-mail: bliznyuk359@gmail.com

Мета. Вивчити набір промислових сортів пшениці м'якої ярої різного екологогеографічного походження та визначити серед них такі, що мають високий потенціал продуктивності в різних екологічних зонах вирощування. Методика. Дослідження проводили впродовж 2016, 2017 рр. у двох екологічних зонах України: Лісостеп (Миронівський інститут пшениці імені В. М. Ремесла НААН) і Полісся (Носівська селекційно-дослідна станція Миронівського інституту пшениці імені В. М. Ремесла НААН) на 14 сортах різного еколого-географічного походження: Елегія миронівська, Струна миронівська, Харківська 26, МІП Злата, Панянка, Сімкода миронівська, Етюд, Сюїта, Героїня (UKR), Koksa, Ясна (POL), Granny (AUT), Leguan (CZE), Venera (SYR). Спостереження і оцінки в польових умовах проводили відповідно до методики державного сортовипробування. Погодні умови 2016 р. в зонах проведення досліджень були оптимальними для розвитку рослин пшениці ярої. У 2017 р. оптимальні погодні умови спостерігали в зоні Полісся, а в Лісостепу вони були посушливими. Результати. Середній рівень урожайності в умовах Миронівського інституту пшениці (Лісостеп) склав 3,61 т/га з коливаннями від 3,14 (min) до 4,20 т/га (max). Більш високу врожайність сорти сформували на Носівський СДС МІП (Полісся), де зволоження в період вегетації виявилось більш оптимальним (ГТК = 1,5). Урожайність в умовах станції (середнє 5,11 т/га) варіювала від 4,62 (min) до 6,03 т/га (max). Високою потенційною продуктивністю характеризувалися сорти, які перевищили рівень урожайності стандарту Елегія миронівська в зонах Лісостепу (МІП) і Полісся (Носівська СДС МІП): Сімкода миронівська, Струна миронівська, МIП Злата, Панянка (UKR), Leguan (CZE), Koksa (POL). Висновки. Cеред досліджуваних сортів пшениці м'якої ярої різного еколого-географічного походження виділено кращі, що характеризуються високим потенціалом продуктивності: для зони Лісостепу - МIП Злата (UKR), Leguan (CZE), Koksa (POL), Панянка, Сімкода миронівська, Харківська 26 (UKR); для зони Полісся - Сімкода миронівська (UKR), Koksa (POL), Leguan (CZE), Струна миронівська, МІПЗлата, Панянка (UKR). Кращими 
сортами для Лісостепу та Полісся є Сімкода миронівська, Струна миронівська, МІП Злата, Панянка (UKR), Koksa (POL), Leguan (CZE), що можуть використовуватись як вихідний матеріал у селекції пшениці ярої та бути рекомендованими для вирощування у цих екологічних зонах.

Ключові слова: пшениця м'яка яра, сорти, продуктивність рослин, екологічні зони

Вступ. Основним напрямом у селекції пшениці $є$ збільшення врожайності. Продуктивність - основна ознака, що характеризує господарську цінність створюваних сортів. На продуктивність пшениці ярої та їі складові суттєво впливають умови довкілля. Особливо актуальними є дослідження впливу екологічних чинників у різних агроекологічних зонах вирощування на процес формування продуктивності сортів пшениці ярої м'якої різного еколого-географічного походження. Створення сортів у певній зоні обумовлює їхню здатність формувати високий урожай саме у цих умовах вирощування. Серед сортів різного еколого-географічного походження максимальний урожай забезпечать лише ті генотипи, що за здатністю формувати продуктивність та адаптивністю добре пристосовані до умов тієї чи іншої грунтово-кліматичної зони вирощування і цілком відповідають їй за своїми параметрами.

Результати досліджень свідчать [1], що сорти пшениці м’якої ярої різного еколого-географічного походження мають розбіжність в урожайності за вирощування в різних екологічних зонах.

Пошук генотипів з високим потенціалом продуктивності для різних зон вирощування з подальшим використанням їх у практичній селекції - надзвичайно актуальний напрям досліджень як для селекційної роботи, так і для вирощування сортів у сільгоспвиробництві.

Аналіз літературних джерел, постановка проблеми. О. О. Жученко відмітив [1], що внесок селекції в підвищення врожайності найважливіших сільськогосподарських культур становить 30-70 \%, а з погляду можливих кліматичних змін роль селекції постійно зростатиме. Останнє пов'язане як із загальною тенденцією до біологізації та екологізації сільськогосподарського виробництва, так і з неухильно зростаючими можливостями самої селекції в управлінні генотиповою мінливістю культивованих видів.

M. І. Вавилов відмічав [2], що найбільші складнощі в селекції пшениці полягають у тому, що в одному сорті необхідно поєднати велику кількість цінних ознак і властивостей. Він має задовольнити вимоги і землероба, і мірошника, і пекаря. Однак, які б не ставилися вимоги, врожайність залишається вирішальним показником цінності селекційного матеріалу для створення нового сорту. 
Кількісні ознаки характеризують найбільш важливі показники, в тому числі величину та якість урожаю, що мають значну мінливість і залежать від факторів зовнішнього середовища. Вивчення їх потребує значної вибірки, яку отримують шляхом неабияких затрат часу і праці [3, 4].

Учені вважають, що неможливо створити сорти, універсальні для всіх зон, екологічних ніш та виробничих умов [5]. Н. С. Попков також указує [6], що незважаючи на погіршення умов вирощування необхідна селекція на високу продуктивність: чим вищі потенційні можливості сорту, тим слабше він реагує на екологічні, погодні та інші зміни.

Під впливом умов року величина врожаю варіює не меншою, а у багатьох випадках навіть більшою мірою при вирощуванні сорту в один рік, але в різних місцях [7]. Урожай визначається потенційними можливостями сорту та його здатністю реалізувати їх у конкретних умовах вирощування [8]. Під дією стрес-факторів (волого-температурних та інших) втрати несуть інтенсивні високопродуктивні сорти, які порівняно з екстенсивними більш чутливі до погодних і кліматичних змін [9].

П. П. Лук'яненко [10] виявив високий позитивний зв'язок продуктивності сорту з урожаєм з одиниці площі і успішно застосовував його при доборі високопродуктивних форм. Цей зв'язок значно варіює залежно від географічної зони, погодних умов і вихідного матеріалу.

Джеромо Ацці [11] досліджував продуктивність насіння, вирощуючи пшеницю в різних за кліматичними умовами географічних пунктах: північ Італії - помірно вологий клімат, а південь - сухий і жаркий. Насіння південної репродукції виявилося більш урожайним, ніж північної. Він пов'язує рівень урожайності та якості насіння з географічним положенням та кліматом тієї місцевості, в якій отримано насіння.

Актуальним завданням сьогодення є оцінювання сортів пшениці м'якої ярої за продуктивністю в різних агроекологічних умовах вирощування та адаптаційною здатністю до дії різних факторів навколишнього середовища.

Мета досліджень - вивчити набір промислових сортів пшениці м'якої ярої різного еколого-географічного походження та визначити серед них такі, що мають високий потенціал продуктивності в різних екологічних зонах вирощування.

Матеріал і методика. Дослідження проводили впродовж 2016, 2017 рр. у двох екологічних зонах України: Лісостеп (Миронівський інститут пшениці імені В. М. Ремесла НААН) та Полісся (Носівська селекційнодослідна станція Миронівського інституту пшениці імені В. М. Ремесла НАAН) на 14 сортах пшениці м'якої ярої різного еколого-географічного походження: Елегія миронівська, Струна миронівська, Харківська 26, 
Злата, Панянка, Сімкода миронівська, Етюд, Сюїта, Героїня (UKR), Koksa, Ясна (POL), Granny (AUT), Leguan (CZE), Venera (SYR).

Сівбу проводили на дослідних полях селекційної сівозміни сівалкою

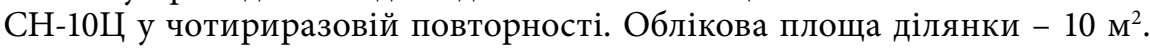
Стандарт - сорт Елегія миронівська.

Спостереження і оцінки в польових умовах проводили відповідно до методики державного сортовипробування [12].

За даними Миронівської агрометеостанції, в цілому вегетаційний період 2016 р. характеризувався підвищенням температури та збільшенням кількості опадів. Так, випало 331 мм опадів, що більше на 59 мм від середньобагаторічних даних. Розподіл опадів за місяцями був нерівномірним упродовж усього вегетаційного періоду. Але слід зауважити, що зливові дощі не призвели до вилягання посівів. Гідротермічний коефіцієнт складав 1,2 в зоні Лісостепу, 1,3 - у Поліссі.

Вегетаційний період пшениці ярої 2017 р. у зоні розташування Миронівського інституту пшениці супроводжувався підвищенням температури та зменшенням кількості опадів. У період сівба-сходи середньодобова температура становила $+7,9^{\circ} \mathrm{C}$ (середньобагаторічний показник $\left.+9,4{ }^{\circ} \mathrm{C}\right)$. Опади $(24,5$ мм) сприяли появі дружних сходів та активному кущінню.

У період сходи-вихід у трубку середньодобова температура в зоні МІП становила $+12,1^{\circ} \mathrm{C}$ (на $1,1^{\circ} \mathrm{C}$ нижче від середніх багаторічних показників), в зоні Носівської СДС $+10,4^{\circ} \mathrm{C}$ (на $0,5{ }^{\circ} \mathrm{C}$ вище середньобагаторічних даних). Опадів за даний період у зоні Лісостепу випало 66,8 мм (середньобагаторічні дані - 24,0 мм). За період вихід у трубку-колосіння середня температура повітря становила $+16,7^{\circ} \mathrm{C}$, що не перевищувало середньобагаторічні дані. У період колосіння-повна стиглість в умовах Лісостепу температура повітря перевищувала середньобагаторічні дані, а для зони Полісся він характеризувався достатньою кількістю опадів, що підвищило вологозабезпеченість грунту і сприяло формуванню врожаю. Загалом за вегетаційний період пшениці ярої 2017 р. у зоні Лісостепу відмічено посушливі погодні умови, у Поліссі - оптимальні за звололоженням і температурним режимом.

Обговорення результатів. Як відомо, рівень урожайності пшениці ярої визначається опадами весняно-літнього періоду (квітень-червень), зокрема їх інтенсивністю і часом випадання. Характеризуючи сприятливість умов середовища для формування продуктивності пшениці, вираховували гідротермічний коефіцієнт (ГТК). Період сівба-сходи 2016 р. у зонах Полісся та Лісостепу був посушливим (ГТК = 0,3 та 0,9 відповідно), сходи-вихід у трубку - оптимальним (ГТК = 1,3 та 1,1 відповідно). Період вихід у трубку-колосіння характеризувався надлишком вологи 
(ГТК $=3,8$ та 2,2 відповідно), а період колосіння-повна стиглість був посушливим (ГТК = 0,7 та 0,8 відповідно), що не сприяло формуванню та наливу зерна. Загалом погодні умови 2016 р. характеризувались оптимальним рівнем зволоження як для зони Полісся (ГТК $=1,3)$, так і для

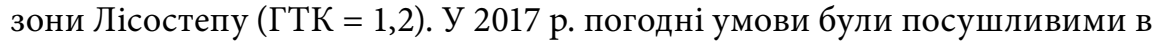
зоні Лісостепу (ГТК $=0,96)$ та оптимальними у зоні Полісся $(Г Т К=1,5)$.

Результати наших досліджень свідчать, що сорти пшениці м'якої ярої різного еколого-географічного походження варіювали за врожайністю в обох екологічних зонах вирощування. Так, в умовах Миронівського інституту пшениці (Лісостеп) середній рівень урожайності становив 3,61 т/га з коливанням від 3,14 т/га (min) до 4,20 т/га (max).

3а 2016, 2017 pp. в зоні Лісостепу рівень урожайності стандарту Елегія миронівська (3,22 т/га) перевищили сорти МIП Злата (UKR), Leguan (CZE), Koksa (POL), Панянка, Сімкода миронівська, Струна миронівська, Харківська 26 (UKR) та інші (табл. 1).

Таблиця 1. Урожайність сортів пшениці м'якої ярої в зоні Лісостепу (МІп, 2016, 2017 рр.), т/га

\begin{tabular}{|c|c|c|c|}
\hline Сорт (країна походження) & $2016 \mathrm{p}$. & $2017 \mathrm{p}$. & середнє \\
\hline Елегія миронівська (UKR), St & 4,60 & 2,74 & 3,22 \\
\hline Злата (UKR) & 5,45 & 2,95 & 4,20 \\
\hline Leguan (CZE) & 4,60 & 3,06 & 3,83 \\
\hline Koksa (POL) & 4,64 & 2,99 & 3,82 \\
\hline Панянка (UKR) & 5,0 & 2,62 & 3,81 \\
\hline Сімкода миронівська (UKR) & 5,01 & 2,61 & 3,81 \\
\hline Харківська 26 (UKR) & 4,74 & 2,74 & 3,74 \\
\hline Струна миронівська (UKR) & 4,89 & 2,59 & 3,74 \\
\hline Venera (SYR) & 4,34 & 2,86 & 3,60 \\
\hline Сюїта (UKR) & 3,86 & 3,16 & 3,51 \\
\hline Granny (AUT) & 4,31 & 2,66 & 3,49 \\
\hline Героїня (UKR) & 4,20 & 2,47 & 3,34 \\
\hline Ясна (POL) & 4,01 & 2,59 & 3,30 \\
\hline Етюд (UKR) & 3,49 & 2,79 & 3,14 \\
\hline $\bar{x}^{\star}$ & 4,53 & 2,91 & 3,61 \\
\hline $\min ^{\star \star}$ & 3,49 & 2,47 & 3,14 \\
\hline $\max ^{\star \star \star}$ & 5,01 & 3,16 & 4,20 \\
\hline $\mathrm{HIP}_{05}$ & \multicolumn{3}{|c|}{0,18} \\
\hline
\end{tabular}

Примітка. Тут і далі $\bar{x}^{\star}-$ середнє, $\min ^{\star \star}-$ мінімальне значення, $\max ^{\star \star \star}-$ максимальне значення

Більш високий рівень урожайності сорти сформували на Носівській СДС МІП (Полісся), де зволоження в період вегетації було більш оптимальним (ГТК $=1,5)$ (табл. 2).

На Поліссі врожайність (середнє 5,11 т/га) варіювала від 4,62 (min) до 6,03 т/га (max). За роки досліджень рівень урожайності стандарту Елегія ми- 
Таблиця 2. Урожайність сортів пшениці м'якої ярої в зоні Полісся (Носівська СДС МІП, 2016, 2017 рр.), т/га

\begin{tabular}{|c|c|c|c|}
\hline Сорт (країна походження) & $2016 p$. & $2017 \mathrm{p}$. & середне \\
\hline Елегія миронівська (UKR), St & 5,25 & 6,40 & 5,53 \\
\hline Сімкода миронівська (UKR) & 5,39 & 6,67 & 6,03 \\
\hline Koksa (POL) & 5,21 & 6,75 & 5,98 \\
\hline Leguan (CZE) & 5,10 & 6,83 & 5,96 \\
\hline Струна миронівська (UKR) & 4,78 & 6,45 & 5,62 \\
\hline МІП Злата (UKR) & 4,66 & 6,54 & 5,60 \\
\hline Панянка (UKR) & 5,37 & 5,80 & 5,59 \\
\hline Харківська 26 (UKR) & 4,51 & 6,25 & 5,38 \\
\hline Ясна (POL) & 4,25 & 6,27 & 5,26 \\
\hline Етюд UKR & 5,18 & 5,27 & 5,23 \\
\hline Venera (SYR) & 4,68 & 5,58 & 5,13 \\
\hline Сюїта (UKR) & 4,60 & 5,62 & 5,11 \\
\hline Героїня (UKR) & 4,58 & 5,27 & 4,92 \\
\hline Granny (AUT) & 4,07 & 5,18 & 4,62 \\
\hline $\bar{x}^{\star}$ & 4,80 & 6,06 & 5,11 \\
\hline $\min ^{\star \star}$ & 4,25 & 5,18 & 4,62 \\
\hline $\max \star * \star$ & 5,39 & 6,83 & 6,03 \\
\hline $\mathrm{HIP}_{05}$ & \multicolumn{3}{|c|}{0,20} \\
\hline
\end{tabular}

ронівська (5,53 т/га) перевищили сорти Сімкода миронівська (UKR), Koksa (POL), Leguan (CZE), Струна миронівська, MIП Злата, Панянка (UKR).

Високим потенціалом продуктивності характеризувалися сорти (табл. 3), що перевищили рівень урожайності стандарту Елегія миронів-

Таблиця 3. Урожайність сортів пшениці м'якої ярої в різних екологічних зонах вирощування (Лісостеп, Полісся, середнє за 2016, 2017 рр.), т/га

\begin{tabular}{|l|c|c|c|}
\hline \multicolumn{1}{|c|}{ Сорт (країна походження) } & Лісостеп & Полісся & Середнє для зон \\
\hline Елегія миронівська (UKR), St & 3,22 & 5,53 & 4,38 \\
Сімкода миронівська (UKR) & 3,81 & 6,03 & 4,92 \\
Злата (UKR) & 4,20 & 5,60 & 4,90 \\
Koksa (POL) & 3,82 & 5,98 & 4,90 \\
Leguan (CZE) & 3,83 & 5,96 & 4,90 \\
Панянка (UKR) & 3,81 & 5,59 & 4,70 \\
Струна миронівська (UKR) & 3,74 & 5,62 & 4,68 \\
Харківська 26 (UKR) & 3,74 & 5,38 & 4,56 \\
Venera (SYR) & 3,60 & 5,13 & 4,37 \\
Сюїта (UKR) & 3,51 & 5,11 & 4,31 \\
Ясна (POL) & 3,30 & 5,26 & 4,28 \\
Етюд (UKR) & 3,14 & 5,23 & 4,19 \\
Героїня (UKR) & 3,34 & 4,92 & 4,13 \\
Granny (AUT) & 3,49 & 4,62 & 4,06 \\
$\bar{x}^{\star}$ & 3,64 & 5,42 & 4,54 \\
min** $_{\text {max** }}^{*}$ & 3,14 & 4,62 & 4,06 \\
HIP $_{05}$ & 4,20 & 6,03 & 4,92 \\
\hline
\end{tabular}


ська в зонах Лісостепу (МІП) та Полісся (Носівська СДС МІП): Сімкода миронівська, МIП Злата (UKR), Leguan (CZE), Koksa (POL), Панянка, Струна миронівська (UKR) та ін.

Пошук генотипів, що мають високий потенціал продуктивності в різних екологічних зонах вирощування, з подальшим використанням їх у практичній селекції $є$ надзвичайно актуальним напрямом досліджень як для селекційної роботи, так і для вирощування сортів у сільгоспвиробництві (див. табл. 3).

Висновки. Виділено сорти пшениці м’якої ярої різного еколого-географічного походження з високим потенціалом продуктивності: для зони Лісостепу - МIП Злата (UKR), Leguan (CZE), Koksa (POL), Панянка, Сімкода миронівська, Харківська 26 (UKR); для зони Полісся - Сімкода миронівська (UKR), Koksa (POL), Leguan (CZE), Струна миронівська, МIП Злата, Панянка (UKR).

Кращими для обох зон є сорти Сімкода миронівська, МІП Злата, Панянка (UKR), Koksa (POL), Leguan (CZE), Струна миронівська (UKR), що можуть використовуватись як вихідний матеріал у селекції пшениці ярої та бути рекомендованими для вирощування у цих екологічних зонах України.

\section{Список використаних джерел}

1. Жученко А. А. Адаптивное растениеводство (эколого-генетические основы). Теория и практика: в 3-х т. Т. 1. Москва : Агрорус, 2008. 814 с.

2. Вавилов Н. И. Научные основы селекции. Москва-Ленинград : Сельхозгиз, 1935. 246 c.

3. Базалій В. В. Принципи адаптивної селекції пшениці озимої в зоні південного степу. Херсон : Айлант, 2004. 244 с.

4. Власенко В. А., Солона В. Й., Федченко Г. В., Ковалишина Г. М., Мельнікова Л. П. Селекція сортів ярої пшениці Елегія миронівська та Соната. Науково-технічний бюлетень Миронівського інституту пшениці імені В. М. Ремесла УААН. Київ : Аграрна наука, 2002. Вип. 2. С. 116-123.

5. Васильчук Н. С., Попов В. М. Селекция яровой твердой пшеницы. Проблемы и пути преодоления засухи в Поволжье. Научные труды НИИСХ Юго-Востока. Саратов, 2000. Ч. 1. С. 14-31.

6. Попков Н. С. Современные сорта озимой пшеницы в Полесье. Зерновые культуры. 1991. № 4. С. 34-35.

7. Кадыров М. А., Гриб С. И., Батуро Ф. Н. Некоторые аспекты селекции сортов с широкой агроэкологической адаптацией. Селекция и семеноводство. 1984. № 7. С. 8-11.

8. Драгавцев В. А. Эколого-генетический скрининг генофонда и методы конструирования сортов сельскохозяйственных растений по урожайности, устойчивости и качеству. Санкт-Петербург: ВИР, 1998. 51 с.

9. Жученко А. А. Главныеприоритетыадаптации растениеводствак неблагоприятным погодным условиям. Пути повышения устойчивости сельскохозяйственного производства в современных условиях : материалы Всероссийской научно-практической конференции (г. Орел, 13-15 июля 2005 г.). Орел : ОрелГАУ, 2005. С. 6-12.

10. Лукьяненко П. П. Выведение новых сортов озимой пшеницы интенсивного типа. Вестник сельскохозяйственной науки. 1970. № 4. С. 54-61. 
11. Ацци Дж. Сельскохозяйственная экология / пер. с англ. Н. А. Емельяновой и др. Москва : Издательство иностранной литературы, 1959. 480 с.

12. Методика державного випробування сортів рослин на придатність до поширення в Україні. Загальна частина / за ред. В. В. Волкодава. Київ : Алефа, 2003. Вип. 1, ч. 3. $106 \mathrm{c.}$

\section{References}

1. Zhuchenko, A. A. (2008). Adaptivnoye rasteniyevodstvo (ekologo-geneticheskiye osnovy). Teoriya i praktika [Adaptive Plant Growing (Ecological and Genetic Bases). Theory and Practice]. (Vol. 1). Moscow: Agrorus. [in Russian]

2. Vavilov, N. I. (1935). Nauchnyye osnovy selektsii [Scientific Bases of Breeding]. Moscow-Leningrad: sel'khozgiz. [in Russian]

3. Bazalii, V. V. (2004). Pryntsypy adaptyvnoi selektsii pshenytsi ozymoi v zoni pivdennoho stepu [Principles of Adaptive Winter Wheat Breeding in the Zone of the Southern Steppe]. Kherson: Ailant. [in Ukrainian]

4. Vlasenko, V. A., Solona, V. Yo., Fedchenko, H. V., Kovalyshyna, H. M., \& Melnikova, L. P. (2002). Breeding the spring wheat varieties Elehiia myronivska and Sonata. Naukovotekhnichnyi biuleten Myronivskoho instytutu pshenytsi im. V. M. Remesla UAAN [Scientific and Technical Bulletin of the V. M. Remeslo Myronivka Institute of Wheat of UAAS], 2, 116-123. [in Ukrainian]

5. Vasil'chuk, N. S., \& Popov, V. M. (2000). Breeding spring durum wheat. Problems and ways to overcome the drought in the Volga region. Nauchnyye trudy NIISKh YugoVostoka [Scientific Works of Agricultural Research Institute for South-East Region], 1, 14-31. [in Russian]

6. Popkov, N. S. (1991). Modern winter wheat varieties in Poles'ye. Zernovyye kul'tury. [Grain Crops], 4, 34-35. [in Russian]

7. Kadyrov, M. A., Grib, S. I., \& Baturo, F. N. (1984). Some aspects of breeding varieties with broad agroecological adaptation. Selektsiya i semenovodstvo [Plant Breeding and Seed Production], 7, 8-11. [in Russian]

8. Dragavtsev, V. A. (1998). Ekologo-geneticheskiy skrining genofonda i metody konstruirovaniya sortov sel'skokhozyaystvennykh rasteniy po urozhaynosti, ustoychivosti $i$ kachestvu [Ecological-genetic screening of the gene pool and methods for designing varieties of agricultural plants for yield, stability and quality]. St. Petersburg: WIR. [in Russian]

9. Zhuchenko, A. A. (2005). The main priorities of the adaptation of crop production to unfavorableweather conditions. In Putipovysheniya ustoychivostisel'skokhozyaystvennogo proizvodstva $v$ sovremennykh usloviyakh: materialy Vserossiyskoy nauchno-prakticheskoy konferentsii [Ways to improve the sustainability of agricultural production in modern conditions: Proc. All-Russian Scientific and Practical Conf.] (pp. 6-12). July 13-15, 2005, Orel, Russia. [in Russian]

10. Luk'yanenko, P. P. (1970). Breeding new winter wheat varieties of intensive type. Vestnik Sel'skokhozyaistvennoy nauki [Bulletin of Agricultural Science], 4, 54-61. [in Russian]

11. Azzi, G. (1959). Sel'skokhozyaistvennaya ekologiya [Agricultural Ecology]. (N. A. Yemelyanova et al., Trans). Moscow: Izdatel'stvo inostrannoy literatury. [in Russian]

12. Volkodav, V. V. (Ed.). (2003). Metodyka derzhavnoho vyprobuvannia sortiv roslyn na prydatnist do poshyrennia v Ukraini. Zahalna chastyna [Methods of State Strain Testing of Crops Suitable for Dissemination in Ukraine. General Part]. Kyiv: N.p. [in Ukrainian] 


\section{Урожайность сортов пшеницы мягкой яровой в разных экологических зонах выращивания}

Близнюк Р. Н., Березовский Д. Ю.

Демидов А. А., доктор сельскохозяйственных наук, член-корреспондент НААН

Хоменко С. О., кандидат сельскохозяйственных наук

Мироновский институт пшеницы имени В. Н. Ремесло НААН Украина, 08853, с. Центральное, Мироновский район Киевской обл. e-mail: bliznyuk359@gmail.com

Цель. Изучить набор промышленных сортов пшеницы мягкой яровой разного эколого-географического происхождения и определить среди них такие, которые имеют высокий потенциал продуктивности в разных экологических зонах выращивания. Методика. Исследования проводились в 2016, 2017 гг. в двух экологических зонах Украины: Лесостепь (Мироновский институт пшеницы имени В. Н. Ремесло НААН) и Полесье (Носовская селекционно-опытная станция Мироновского института пшеницы имени В. Н. Ремесло НААН) на 14 сортах разного эколого-географического происхождения: Елегія миронівська, Струна миронівська, Харківська 26, МІП Злата, Панянка, Сімкода миронівська, Етюд, Сюїта, Героїня (UKR), Koksa, Ясна (POL), Granny (AUT), Leguan (CZE), Venera (SYR). Наблюдения и оценки в полевых условиях проводили в соответствии с методикой государственного сортоиспытания. Погодные условия 2016 г. в зонах проведения исследований были оптимальными для развития растений пшеницы яровой. В 2017 г. оптимальные погодные условия наблюдали в зоне Полесья, а в Лесостепи они были засушливыми. Результаты. Средний уровень урожайности в условиях Мироновского института пшеницы (Лесостепь) составил 3,61 т/га с колебаниями от 3,14 (min) до 4,20 т/га (max). Более высокую урожайность сорта сформировали на Носовской СОС МИП (Полесье), где увлажнение в период вегетации оказалось более оптимальным (ГТК = 1,5). Урожайность в условиях станции (среднее 5,11 т/га) варьировала от 4,62 ( $\min )$ до 6,03 т/га (max). Высокой потенциальной продуктивностью характеризовались сорта, которые превысили уровень урожайности стандарта Елегія миронівська в зонах Лесостепи (МИП) и Полесья (Носовская СОС МИП): Сімкода миронівська, Струна миронівська, МIП Злата, Панянка (UKR), Leguan (CZE), Koksa (POL). Выводы. Среди изучаемых сортов пшеницы мягкой яровой разного эколого-географического происхождения выделены лучшие, характеризующиеся высоким потенциалом продуктивности: для зоны Лесостепи - МIП Злата (UKR), Leguan (CZE), Koksa (POL), Панянка, Сімкода миронівська, Харківська 26 (UKR); для зоны Полесья - Сімкода миронівська (UKR), Koksa (POL), Leguan (CZE), Струна миронівська, MIП Злата, Панянка (UKR). Лучшими сортами для Лесостепи и Полесья являются Сімкода миронівська, Струна миронівська, МIП Злата, Панянка (UKR), Koksa (POL), Leguan (CZE), которые могут использоваться как исходный материал в селекции пшеницы яровой и быть рекомендованими для выращивания в этих экологических зонах.

Ключевые слова: пшеница мягкая яровая, сорта, продуктивность растений, экологические зоны 


\title{
Yielding capacity of bread spring wheat in different agro-ecological zones
}

\author{
Blyzniuk R. M. , Berezovskyi D. Yu. \\ Demydov O. A., Doctor of Agricultural Sciences, Associate Member of NAAS \\ Khomenko S. O., Candidate of Agricultural Sciences
}

The V.M. Remeslo Myronivka Institute of Wheat of NAAS

Tsentralne village, Myronivka district, Kyiv region, 08853, Ukraine

e-mail: bliznyuk359@gmail.com

Purpose. To study set of cultivated bread wheat varieties of different ecological and geographical origin and to identify those with high productivity potential in different agroecological zones. Methods. The research was conducted during 2016, 2017 in two ecological zones of Ukraine: Forest-Steppe (the V. M. Remeslo Myronivka Institute of Wheat of NAAS) and Polissia (Nosivka Plant Breeding and Experimental Station of the V. M. Remeslo Myronivka Institute of Wheat of NAAS) with 14 varieties of different ecological and geographical origin Elehiia myronivska, Struna myronivska, Kharkivska 26, Zlata, Panianka, Simkoda myronivska, Etiud, Siuita, Heroinia (UKR), Koksa, Yasna (POL), Granny (AUT), Leguan (CZE), Venera (SYR). Field observations and assessments were carried out in accordance with the method of the State strain testing. Weather conditions in 2016 in the research zones were optimal for development of spring wheat plants. In 2017, optimal weather conditions were observed in the Polissia zone, and in the Forest-Steppe they were arid. Results. The average yield at Myronivka Institute of Wheat (Forest-Steppe) was $3.61 \mathrm{t} / \mathrm{ha}$ with fluctuations from $3.14(\mathrm{~min})$ to $4.20 \mathrm{t} / \mathrm{ha}(\max )$. Higher yields were formed at Nosivka PBES MIW (Polissia), where moisture during vegetation period was more optimal ( $\mathrm{HTC}=1.5)$. At the station yield level (average $5.11 \mathrm{t} / \mathrm{ha}$ ) varied from $4.62(\mathrm{~min})$ to $6.03 \mathrm{t} / \mathrm{ha}(\mathrm{max})$. The varieties Simkoda myronivska, Struna myronivska, MIP Zlata, Panianka (UKR), Leguan (CZE), Koksa (POL) were characterized with high productivity potential and exceeded the yield level of the standard variety Elehiia myronivska in the Forest-Steppe (MIW) and Polissia (Nosivka PBES MIW) zones. Conclusions. Among the bread spring wheat varieties studied of different ecological and geographical origin, the best varieties characterized with high potential of productivity were identified: for the zone of Forest-Steppe - MIP Zlata (UKR), Leguan (CZE), Koksa (POL), Panianka, Simkoda myronivska, Kharkivska 26 (UKR), for the Polissia zone - Simkoda myronivska (UKR), Koksa (POL), Leguan (CZE), Struna myronivska, MIP Zlata, Panianka (UKR). The varieties Simkoda myronivska, Struna myronivska, MIP Zlata, Panianka (UKR), Koksa (POL), Leguan (CZE) were the best for both the Forest-Steppe and Polissia zones. These varieties can be used as the initial material in spring wheat breeding and be recommended for growing in these ecological zones.

Key words: bread spring wheat, varieties, plant productivity, ecological zones 